\title{
GAMBARAN HASIL PEMERIKSAAN SKRINING RPR- TP rapid, Anti-HIV dan HBsAg PADA IBU HAMIL DI PUSKESMAS KECAMATAN CIRACAS
}

\author{
Retno Martini Widhyasih" ${ }^{1)}$, Lenggo Geni' ${ }^{2)}$, Prima Nanda Fauziah ${ }^{2)}$, Vira Amalia ${ }^{2)}$ \\ ${ }^{1}$ Poltekkes Kemenkes Jakarta III \\ ${ }^{2}$ Program Studi Analis Kesehatan, Fakultas Kesehatan, Universitas Mohammad Husni Thamrin \\ Correspondence author:Lenggo Geni, lenggogeni19@gmail.com, Jakarta, Indonesia
}

\begin{abstract}
ABSTRAK
Infeksi menular seperti HIV (Human Immunodeficiency Virus), Sifilis dan Hepatitis B merupakan penyakit menular langsung yang dapat menginfeksi ibu dan ditularkan ke bayi sejak dalam kandungan, persalinan maupun menyusui memiliki cara penularan yang hampir sama, infeksi ini akan menimbulkan resiko penularan yang akan terjadi pada bayi lahir dengan infeksi kongenital, premature, keguguran (abortus) bahkan kematian. Sehingga menurut permenkes no. 52 tahun 2017 perlu dilakukan pemeriksaan skrining menggunakan HIV rapid test, RPR (Rapid Plasma Reagin)-Tp rapid (Treponema pallidum rapid) dan HBsAg (Hepatitis B surface Antigen) rapid test pada ibu hamil. Penelitian ini bertujuan untuk mengetahui gambaran hasil pemeriksaan skrining RPR-Treponema pallidum rapid, anti-HIV dan HBsAg pada ibu hamil di Puskesmas Kecamatan Ciracas periode Januari-April 2019 dengan menggunakan metode deskriptif. Setelah dilakukan penelitian terhadap 951 ibu hamil, didapatkan data ibu hamil yang melakukan pemeriksaan skrining terbanyak pada trimester ke 2 sebanyak 427 orang ibu hamil $(44,90 \%)$ dengan hasil reaktif sebanyak 3 orang ibu hamil $(0,32 \%)$ pada pemeriksaan RPR-TP rapid, pada pemeriksaan anti-HIV didapata hasil reaktif 1 orang ibu hamil $(0,11 \%)$ serta hasil reaktif 5 orang ibu hamil $(0,53 \%)$ pada pemeriksaan HBsAg. Pemeriksaan skrining bagi ibu hamil sangat penting untuk membantu menekan angka prevalensi bayi lahir dengan terinfeksi sifilis, HIV dan hepatitis B. Semakin cepat diketahui maka semakin baik pengobatan yang diberikan untuk ibu dan janin. Sehingga program triple eliminasi HIV(Human Immunodeficiency Virus), Sifilis dan Hepatitis B dapat tercapai.
\end{abstract}

Kata Kunci $\quad$ : Anti-HIV, HBsAg, RPR-Tp rapid, Ibu Hamil

\section{ABSTRACT}

Infectious infections such as HIV (Human Immunodeficiency Virus), Syphilis and Hepatitis B are direct infectious diseases that can infect the mother and be transmitted to the baby since in the womb, childbirth and breastfeeding have almost the same mode of transmission, this infection will pose a risk of transmission that will occur in babies born with congenital infections, premature, miscarriage (abortion) and even death. So according to Permenkes no. 52 of 2017, it is necessary to carry out a screening examination using HIV rapid test, RPR (Rapid Plasma Reagin) Tp rapid (Treponema pallidum rapid) and HBsAg (Hepatitis B surface Antigen) rapid test in pregnant women. This study aims to describe the results of the RPR-Treponema pallidum rapid, anti-HIV and HBsAg screening examination in pregnant women at the Ciracas District Health Center for the period January-April 2019 using descriptive methods. After conducting research on 951 pregnant women, it was found that data on pregnant women who performed the most screening examinations in the second trimester were 427 pregnant women (44.90\%) with reactive results of 3 pregnant women $(0.32 \%)$ on the RPR examination. TP rapid, on the anti-HIV examination, there were data on reactive results of 1 pregnant women $(0.11 \%)$ and reactive results of 5 pregnant women $(0.53 \%)$ on HBsAg examination. Screening for pregnant women is very important to help reduce the prevalence of babies born infected with syphilis, HIV and hepatitis B. The sooner it is known, the better the treatment given to the mother and fetus. So that the triple elimination program of HIV (Human Immunodeficiency Virus), Syphilis and Hepatitis B can be achieved.

Keywords: Anti-HIV, HBsAg, RPR-Tp rapid, pregnant women

Open Journal System (OJS): journal.thamrin.ac.id

http://journal.thamrin.ac.id/index.php/anakes/issue/view/35 


\section{PENDAHULUAN}

Beberapa infeksi menular seperti HIV (Human Immunodeficiency Virus), Sifilis dan Hepatitis B merupakan penyakit menular langsung yang dapat menginfeksi ibu dan ditularkan ke bayi sejak dalam kandungan, persalinan maupun menyusui. Dalam upaya menurunkan kematian ibu serta melahirkan generasi yang sehat dan berkualitas yang merupakan tujuan pelayanan kesehatan ibu (Kemenkes RI, 2015).

Infeksi HIV, Sifilis dan Hepatitis B memiliki jalur penularan yang sama yaitu melalui seksual, darah dan vertikal dari ibu ke anak. Penularan dari ibu ke janin terjadi selama kehamilan melalui plasenta yang terinfeksi, melalui darah atau cairan genital saat persalinan dan melalui ASI (Air Susu Ibu) pada masa laktasi. Pada infeksi sifilis kontak dengan lesi sifilis setelah persalinan juga dapat menularkan sifilis pada anak/bayi. Ketiga kondisi infeksi ini dapat memperburuk satu sama lain. Berbagai penelitian dibanyak negara melaporkan bahwa infeksi sifilis dapat meningkatkan risiko penularan HIV sebesar 3-5 kali (Kemenkes RI, 2015).

Prevalensi infeksi HIV, Sifilis dan Hepatitis B menurut WHO (World Health Organization) pada tahun 2016 Asia menyumbang sekitar 50\% kasus IMS (Infeksi Menular Seksual). Pada tahun 2012 menurut Global UNAIDS (United Nations Programme on HIV/AIDS) menunjukkan bahwa jumlah penderita HIV di dunia mencapai 34 juta orang. Menurut WHO pada tahun 2012 untuk sifilis dan hepatitis B berturutturut terdapat 45 juta kasus sifilis sedangkan hepatitis B mencapai 240 juta orang di dunia sebagai penderita hepatitis B. Di Indonesia menurut laporan Kemenkes pada tahun 2017 sebanyak 48.300 orang yang dilaporkan terinfeksi HIV, sebanyak 21,8\% yang terinfeksi hepatitis B serta terdapat 28.900 kasus infeksi sifilis. Menurut data Kemenkes 2017 prevalensi infeksi HIV, Sifilis dan Hepatitis B pada ibu hamil di Indonesia berturut-turut sebesar $0,3 \%, 1,7 \%$ dan $2,5 \%$.

Pada saat kehamilan mulai berlangsung, maka janin akan menerima makanan dari darah melalui plasenta. Bila plasenta terjadi peradangan maka virus atau bakteri akan tembus melalui plasenta sehingga terjadi penularan dari ibu ke anak. 
HIV, Sifilis dan Hepatitis B memiliki cara penularan yang hampir sama pada ibu hamil. Infeksi ini akan menimbulkan resiko penularan pada bayi yang lahir dari ibu yang terinfeksi sehingga bayi yang lahir memiliki resiko infeksi kongenital, premature, keguguran (abortus) bahkan kematian.

Ibu hamil wajib diberi tahu tentang kemungkinan infeksi menular seksual dengan diadakan proses skrining untuk meningkatkan kesehatan ibu (Carey, Ravi, Chandra, Desai, \& Neal, 2010). Sesuai dalam UU nomor 36 tahun 2009 tentang Kesehatan yang kemudian pemerintah mengeluarkan Permenkes No. 52 tahun 2017 tentang Eliminasi Penularan Human Immunidediciency Virus, Sifilis, dan Hepatitis B dari Ibu ke Anak. Untuk melaksanakan kegiatan deteksi dini yang dilakukan oleh tenaga kesehatan di setiap pelayanan kesehatan melalui pemeriksaan darah pada ibu hamil paling sedikit satu kali pada masa kehamilan sebagai upaya eliminasi penularan dari ibu ke janin. Pemeriksaan skrining yang digunakan HIV rapid test, RPR (Rapid Plasma Reagin)-Tp rapid (Treponema pallidum rapid) dan HBsAg (Hepatitis B surface Antigen) rapid test (Kementerian Kesehatan RI, 2017).

Pengambilan data dilakukan di Puskesmas Kecamatan Ciracas dikarenakan banyaknya ibu hamil yang melakukan pemeriksaan RPR-Tp rapid, anti-HIV dan HBsAg sebagai pemeriksaan skrining wajib pada kehamilan.Berdasarkan latar belakang diatas maka peneliti ingin melakukan penelitian tentang Gambaran hasil pemeriksaan skrining RPR-Tp rapid, anti-HIV dan HBsAg pada ibu hamil di Puskesmas Kecamatan Ciracas.

\section{METODE}

Penelitian ini dilakukan di Puskesmas Ciracas, Jakarta Timur pada bulan Agustus 2019. Populasi dalam penelitian ini adalah wanita hamil yang melakukan pemeriksaan laboratorium di Puskesmas Ciracas, Jakarta Timur pada bulan Januari-April 2019.Sampel yang digunakan dalam penelitian ini adalah hasil pemeriksaan wanita hamil yang melakukan pemeriksaan anti-HIV, RPR-Tp rapid dan HBsAg di Puskesmas Ciracas, Jakarta Timur pada Januari-April 2019. 


\section{HASIL DAN PEMBAHASAN}

Dari data pemeriksaan skrining RPR-Tp rapid, Anti-HIV dan HBsAg terhadap 951 ibu hamil di Puskesmas Kecamatan Ciracas pada bulan Januari-April 2019 diperoleh data sekunder hasil seperti tertera pada Tabel 1 .

Tabel 1.

Data Ibu Hamil yang Melakukan Pemeriksaan Skrining Berdasarkan Trimester (Usia) Kehamilan pada bulan Januari-April 2019

di Puskesmas Ciracas.

\begin{tabular}{ccc}
\hline $\begin{array}{c}\text { Ibu Hamil } \\
\text { (usia kehamilan) }\end{array}$ & Jumlah & Persentase \\
\hline Trimester 1 & 323 & $33,96 \%$ \\
\hline Trimester 2 & 427 & $44,90 \%$ \\
\hline Trimester 3 & 201 & $21,14 \%$ \\
\hline Jumlah & $\mathbf{9 5 1}$ & $\mathbf{1 0 0 \%}$ \\
\hline
\end{tabular}

Pada Tabel 1, didapat jumlah kunjungan ibu hamil yang melakukan pemeriksaan skrining di Puskesmas Kecematan Ciracas berjumlah total 951 ibu hamil dengan 323 ibu hamil (33,96\%) pada trimester 1, $427 \mathrm{ibu}$ hamil $(44,90 \%)$ pada trimester 2 dan $201 \mathrm{ibu}$ hamil $(21,14 \%)$ pada trimester 3.

Tabel 2.

Persentase Hasil Pemeriksaan Skrining RPR, Anti-HIV dan HBsAg pada Ibu Hamil di Puskesmas Ciracas pada bulan Januari-April 2019.

\begin{tabular}{cccc}
\hline Pemeriksaan & NR (\%) & R (\%) & Jumlah \\
\hline RPR-Tp rapid & $948(99,68)$ & $3(0,32)$ & $951(100 \%)$ \\
\hline Anti-HIV & $950(99,89)$ & $1(0,11)$ & $951(100 \%)$ \\
\hline HBsAg & $946(99,47)$ & $5(0,53)$ & $951(100 \%)$ \\
\hline
\end{tabular}

Berdasarkan 951 orang ibu hamil, didapat hasil pemeriksaan skrining RPR-Tp rapid dengan hasil reaktif pada 3 orang ibu hamil $(0,32 \%)$ dan non-reaktif 948 orang ibu hamil $(99,68 \%)$, Anti-HIV sebanyak 1 orang ibu hamil $(0,11 \%)$ dengan hasil reaktif dan 951 orang ibu hamil $(99,89 \%)$ dengan hasil non-reaktif, sedangkan pada pemeriksaan skrining HBsAg didapatkan hasil reaktif pada 5 orang ibu hamil (0,53\%) dan 946 orang ibu hamil $(99,47 \%)$ dengan hasil non-reaktif. 
Pada pemeriksaan skrining RPR-Tp rapid, Anti-HIV dan HBsAg pada 951 orang ibu hamil di bulan Januari-April 2019 di Puskesmas Ciracas pada penelitian ini didapatkan hasil ibu hamil yang melakukan pemeriksaan skrining RPR-Tp rapid, Anti-HIV dan HBsAg paling banyak ditemukan pada trimester 2 sebesar 44,90\% (Tabel 1) hal ini sudah sesuai dengan peraturan yang dikeluarkan pemerintah Permenkes No. 52 tahun 2017 yang mewajibkan ibu hamil melakukan pemeriksaan darah paling sedikit satu kali pada masa kehamilan supaya mengurangi penularan penyakit dari ibu ke janin hal ini juga didukung oleh teori (Harald et al., 2015) yang mengatakan ibu hamil harus di skrining secara serologis untuk awal kehamilan (kunjungan pranatal pertama) karena jika hasil dari pemeriksaan skrining reaktif akan cepat dilakukan pengobatan serta pencegahan penularan infeksi pada bayi.

Pada Tabel 2. didapatkan hasil pemeriksaan skrining RPR-Tp rapid dengan hasil reaktif pada 3 orang ibu hamil (0,32\%) dan non-reaktif 948 orang ibu hamil (99,68\%), Anti-HIV sebanyak 1 orang ibu hamil (0,11\%) dengan hasil reaktif dan 951 orang ibu hamil $(99,89 \%)$ dengan hasil non-reaktif, sedangkan pada pemeriksaan skrining HBsAg didapatkan hasil reaktif pada 5 orang ibu hamil (0,53\%) dan 946 orang ibu hamil $(99,47 \%)$ dengan hasil non-reaktif.

Berdasarkan hasil pemeriksaan skrining RPR-Tp rapid didapatkan hasil non-reaktif sebanyak 948 ibu hamil (99,68\%) serta hasil reaktif pemeriksaan RPR-Tp rapid sebanyak 3 orang ibu hamil $(0,32 \%)$ pada trimester 2 dari penelitian ini hasil non-reaktif lebih besar namun jumlah ini juga tidak boleh dibiarkan karena sifilis adalah penyakit menular seksual yang berbahaya yang akan menimbulkan kondisi yang cukup parah. Sifilis dapat ditularkan secara vertikal (langsung) dari ibu ke janin selama kehamilan hingga persalinan (Domingues et al., 2014) yang apabila tidak diobati dengan baik akan menyebebakan abortus, bayi lahir mati atau infeksi kongenital yang paling sederhana adalah kebutaan (Badan Penelitian dan Pengembangan Kesehatan, 2013). Hasil penelitian ini juga didukung dari penelitian sebelumnya oleh (Sinaga, 2019) 10\% dengan hasil reaktif sifilis dan 90\% menunjukan hasil non-reaktif yang mengatakan walaupun hasil reaktif lebih sedikit dibanding non-reaktif tapi dapat dianggap mudah karena pengaruh 
sifilis terhadap kehamilan sangat besar akan menyebabkan persalinan kurang bulan, kematian janin dalam rahim, atau bayi lahir dengan menimbulkan kecacatan.

Pada pemeriksaan anti-HIV didapat hasil 1 orang ibu hamil $(0,11 \%)$ dinyatakan reaktif dengan hasil nonreaktif $950 \mathrm{ibu}$ hamil sebesar (99,89\%) dengan hasil penelitian ini walaupun banyak hasil yang non-reaktif namun hal ini tidak boleh dianggap mudah karena HIV pada ibu hamil dapat ditularkan pada masa kehamilan yaitu melalui infeksi atau kerusakan barier plasenta yang kemudian HIV dapat menembus plasenta sehingga terjadi penularan dari ibu ke anak. Resiko penularan dari ibu ke anak lebih besar saat persalinan normal karena tekanan pada plasenta meningkat sehingga bisa menyebabkan terjadinya hubungan darah ibu dan darah bayi. Selain itu, bayi terpapar darah dan lendir ibu dijalan lahir (Kemenkes, 2015). Hasil reaktif ditemukan pada ibu hamil di trimester 3 yang artinya terdapat antibodi Human Immunodeficiency Virus didalam darah ibu hamil yang langsung dilakukan pemantauan terhadap ibu hamil. Usia kehamilan pada trimester 3 ini artinya sudah mendekati persalinan yang pada akhirnya lebih disarankan untuk melahirkan secara seksio sesaria karena dapat menurunkan resiko tertular HIV pada bayi hal ini juga didukung oleh Kemenkes tahun 2015 yang mengatakan persalinan aman bagi ibu dengan HIV adalah menurunkan risiko penularan HIV dari ibu ke bayi, serta risiko terhadap ibu, tim penolong (medis/non-medis) dan pasien lainnya. Persalinan melalui bedah sesar berisiko lebih kecil untuk penularan terhadap bayi, walaupun akan menambah risiko lainnya untuk ibu. Risiko penularan pada persalinan per vaginam dapat diperkecil dan cukup aman bila ibu mendapat pengobatan ARV selama setidaknya enam bulan dan/atau viral load kurang dari $1000 \mathrm{kopi} / \mathrm{mm} 3$ pada minggu ke 36. Ibu hamil juga melakukan terapi ARV (Antiretrovirus) hal ini didukung dengan pedoman Kemenkes tahun 2015 yang mengatakan bahwa pemerian ARV dilakukan tanpa memandang umur kehamilan, stadium klinik dan jumlah CD4. Hasil penelitian ini juga didukung dari penelitian sebelumnya oleh (Sinaga, 2019) $10 \%$ dengan hasil reaktif HIV dan 90\% menunjukan hasil non-reaktif yang mengatakan walaupun hasil reaktif kecil namun Infeksi HIV akan meningkatkan gangguan pertumbuhan pada janin dan persalinan yang beresiko pada wanita yang mengalami penurunan kadar CD4 terinefeksi HIV. 
Hasil pada pemeriksaan HBsAg didapatkan hasil non-reaktif 946 ibu hamil $(99,46 \%)$ dan hasil reaktif 5 orang ibu hamil $(0,53 \%)$ yang berada pada 2 orang ibu hamil di trimester 1 dan 3 orang ibu hamil di trimester 2 yang sedang terinfeksi virus Hepatitis B karena hasil HBsAg reaktif yang artinya ditemukan antigen hepatitis B virus di dalam darah ibu hamil. Hasil ini juga didukung oleh penelitian (Sinaga, Latif, \& Pangulu, 2018) bahwa 13\% sempel reaktif terinfeksi Hepatitis B dan 87\% diperoleh hasil non-reaktif. Meskipun dari hasil penelitian ini didapatkan jumlah terbanyak hasil non-reaktif dibanding reaktif namun pemeriksaan HBsAg tetap penting dimana mengingat infeksi HBV (Hepatitis B Virus) 90\% dapat menjadi kronis jika ditularkan ke bayi, kanker hati, bahkan menimbulkan kematian (Boedina, 2010) dan yang menjadi perhatian adalah penularan HBV dapat membahayakan keselamatan ibu dan bayi masa kehamilan hingga persalinan. Karena sebuah studi menunjukan bahwa infeksi HBV kronis dapat meningkatkan resiko persalinan premature bahkan kematian janin (Han et al., 2012).

Dengan pengobatan serta penanganan yang baik sangat dibutuhkan untuk menekan angka prevalensi ibu yang terinfeksi Sifilis, HIV dan Hepatitis B untuk membuat kemungkinan tidak menularkan ke bayi. Beberapa kemungkinan yang dapat menularkan Sifilis, HIV dan Hepatitis B pada ibu hamil yaitu bergantiganti pasangan seks, memiliki pekerjaan sebagai WPS (wanita pekerja seks) dan pengguna narkoba suntik namun pada penelitian ini tidak diketahui apa pekerjaan.

Pada hasil penelitian pemeriksaan skrining RPR-Tp rapid, Anti-HIV dan HBsAg didapatkan tingginya hasil non-reaktif hal ini dapat mengindikasikan keberhasilan program pemerintah untuk melakukan pemeriksaan skrining laboratorium terhadap Sifilis, HIV dan Hepatitis B yang sesuai dengan permenkes no. 52 tahun 2017 tentang Eliminasi Penularan Human Immunidediciency Virus, Sifilis dan Hepatitis B dari Ibu ke Anak. Program ini dapat membantu menekan angka prevalensi bayi lahir premature, infeksi kongenital hingga kematian.

\section{SIMPULAN}

Didapat jumlah kunjungan ibu hamil yang melakukan pemeriksaan skrining di Puskesmas Kecematan Ciracas berjumlah total $951 \mathrm{ibu}$ hamil dengan $323 \mathrm{ibu}$ hamil (33,96\%) pada trimester 1, 427 ibu hamil 
(44,90\%) pada trimester 2 dan $201 \mathrm{ibu}$ hamil (21,14\%) pada trimester 3. Pemeriksaan skrining RPR dengan hasil reaktif pada 3 orang ibu hamil (0,32\%) dan non-reaktif 948 orang ibu hamil (99,68\%). Pemeriksaan Anti-HIV sebanyak 1 orang ibu hamil (0,11\%) hasil reaktif dan 950 orang ibu hamil $(99,89 \%)$ hasil non-reaktif. Pemeriksaan skrining HBsAg didapatkan hasil reaktif pada 5 orang ibu hamil (0,53\%) dan 946 orang ibu hamil (99,47\%) dengan hasil non-reaktif.

\section{UCAPAN TERIMA KASIH}

Penulis mengucapkan terima kasihh kepada Prodi D III Analis Kesehatan Universitas MH Thamrin berperan serta dalam penelitian ini.

\section{DAFTAR PUSTAKA}

1. Amadi, E. S., Ononiwu, C. E., Aballa, N., Oladimeji, S. A., Aneke, F. A., \& Ugwuoru, D. C. (2010). Prevalence of syphilis among patients in a dental clinic in Enugu, Nigeria. Pakistan Journal of Medical Sciences, 26(1), 59-61.

2. Amrullah, Muhammad Rizalul Fahmi. (2017). Perbedaan Hasil Anti-Hbs Menggunakan Metode Rapid Test Dan Elisa. 6-21.

3. Astuti, Mifta Yulia, Susi Dyah Puspowati, SP., M. S. (2018). Hubungan Pengetahuan dan Perilaku Kadarzi (Keluarga Sadar Gizi) dengan Kejadian Anemia Ibu Hamil di Puskesmas Sambi I Kabupaten Boyolali. Retrieved from http://eprints.ums.ac.id/id/eprint/67865

4. Astuti, D. P., \& Sulastri, E. (2019). Universitas Muhammadiyah Purworejo Peningkatan Pengetahuan Kehamilan, Persalinan Dan Nifas Yang Sehat Melalui Kelas Ibu Hamil Increasing Knowledge Of Pregnancy, Labor And Postpartum The 9 Th University Research Colloqium 2019 Universitas Muhammadiyah Pu. 7-10.

5. Badan Penelitian dan Pengembangan Kesehatan. (2013). Pedoman Tata Laksana Sifilis. Retrieved from http://siha.depkes.go.id/portal/files_upload/Pedoman_Tatalaksana_Sifilis_Puskesmas__merah_ok. pdf

6. Badan Penelitian dan Pengembangan Kesehatan/Kementerian Kesehatan RI. (2013). Penyakit Menular Non-Neglected.

7. Boedina, S. (2010). Diagnosis dan Prosedur Laboratorium. Jakarta: Fakultas Kedokteran Universitas Indonesia.

8. Carey, M. P., Ravi, V., Chandra, P. S., Desai, A., \& Neal, D. J. (2010). Prevalence of HIV, Hepatitis B, syphilis, and chlamydia among adults seeking treatment for a mental disorder in southern India. AIDS and Behavior, 11(2), 289-297. https://doi.org/10.1007/s10461-006-9134-2 
9. $\quad$ Depkes. (2014). Infodatin AIDS.pdf. Situasi Dan Analisis HIV AIDS.

10. Domingues, R. M. S. M., Szwarcwald, C. L., Junior, P. R. B. S., \& Leal, M. do C. (2014). Prevalence of syphilis in pregnancy and prenatal syphilis testing in Brazil: Birth in Brazil study. Revista de Saude Publica. https://doi.org/10.1590/S0034-8910.2014048005114

11. Efrida, E. (2014). Imunopatogenesis Treponema pallidum dan Pemeriksaan Serologi. Jurnal Kesehatan Andalas, 3(3), 572-587.

12. Hahn, Andrew W. \& Barbee, L. A. (2018). Epidemiology in the United States Incidence trends in the united States. (syphilis), 73.

13. Han, G. R., Xu, C. L., Zhao, W., \& Yang, Y. F. (2012). Management of chronic hepatitis B in pregnancy. World Journal of Gastroenterology, 18(33), 4517-4521. https://doi.org/10.3748/wjg.v18.i33.4517

14. Harald, M., Sigurd, G., Werner, M., U.S. Department of Health and Human Services, Reed, B. D., Gorenflo, D. W., ... Foxman, B. (2015). Vulvovaginal candidiasis: epidemiology, microbiology and risk factors. In Critical reviews in microbiology (Vol. 9). https://doi.org/10.3109/1040841X.2015.1091805

15. Harrison. (2012). 'Penyakit Spiroketa', dalam Prinsip-Prinsip Ilmu Penyakit Dalam.o Title. 'Penyakit Spiroketa', Dalam Prinsip-Prinsip Ilmu Penyakit Dalam., 2(Ed. Lukerhart, Sheila A. \& Holmes, King K. Trans. Asdie, Ahmad H. Vol. 2. Jakarta., EGC.).

16. Jawetz. (2016a). Jawetz, Melnick \& Adelberg's Medical Microbiology. In Journal of Molecular Biology (27th ed., Vol. 301). United States of America: McGraw-Hill Education.

17. Jawetz, M. \& A. (2016b). Mikrobiologi Kedokteran Jawet, Melnick \& Adelberg 27th Ed.

18. Kemenkes. (2015). Pedoman Pelaksanaan Pencegahan Penularan Hiv Dan Sifilis Dari Ibu Ke Anak Bagi Tenaga Kesehatan.

19. Kemenkes. (2017). Situasi Penyakit Hepatitis B di Indonesia Tahun 2017. MOH Website, 151, 1017. https://doi.org/10.1145/3132847.3132886

20. Kemenkes RI. (2015). Pedoman Manajemen Program Pencegahan Penularan Hiv Dan Sifilis Dari Ibu Ke Anak.

21. Kemenkes RI. (2017). Berita Negara. Menteri Kesehatan Republik Indonesia Peraturan Menteri Kesehatan Republik Indonesia, Nomor 65(879), 2004-2006. https://doi.org/10.1093/bioinformatics/btk045

22. Kemenkes RI. (2018). InfoDatin-HIV-AIDS-2018.pdf(p. 12). p. 12.

23. Kementerian Kesehatan RI. (2014). Infodatin: Situasi dan Analisi Hepatitis. Pusat Data Dan Informasi, p. 8. https://doi.org/24427659

24. Kementerian Kesehatan RI. (2017). Peraturan Menteri Kesehatan Republik Indonesia Nomor 52 Tahun 2017 Tentang Eliminasi Penularan HIV, Sifilis dan Hepatitis B dari Ibu ke Anak. MenKes RI, 1-36. 